\title{
Prevalence and associated factors of depression among patients with HIV/AIDS in Hawassa, Ethiopia, cross-sectional study
}

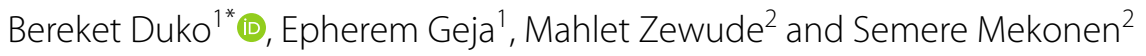

\begin{abstract}
Background: Globally, 350 million people are affected by depression and 800,000 people die due to suicide every year due to depression. People living with HIV/AIDS face different challenges, including HIV-related perceived stigma, lack of social support and also depression. This study aimed to assess prevalence and factors associated with depressive symptom among people living with HIV/AIDS attending Hawassa University Comprehensive Specialized Hospital, Hawassa, Ethiopia.

Methods: Hospital-based cross-sectional study was implemented in 2016. A total of 401 HIV-positive patients who had regular visit at Hawassa University Comprehensive Specialized Hospital, Hawassa, Ethiopia were included in the study. Systematic random sampling technique was used to recruit study participants. Patient Health Questionnaire item nine (PHQ-9) was used to assess depressive symptoms. In addition to this, Oslo social support scale and HIV perceived stigma scale were used to assess social support and HIV-related perceived stigma, respectively.
\end{abstract}

Results: A total of 401 study participants were included in the study, giving a response rate of $96.2 \%$. The mean age of the respondents was 38 years (SD \pm 10.23 ). This study revealed that $48.6 \%$ of HIV-positive patients had depression. Patients who had poor social support $[A O R=2.53,(95 \% \mathrm{Cl} 1.70,9.13)]$, HIV-related perceived stigma [AOR $=2.83,(95 \%$ $\mathrm{Cl} 1.78,4.48)]$ and $C D 4$ cell count $<200[\mathrm{AOR}=3.89$, $(95 \% \mathrm{Cl} 1.02,14.83)]$ were more likely to have depression as compared to individuals who had good social support, no perceived HIV stigma and CD4 cell count $>200$, respectively.

Conclusion: Having poor social support, HIV-related perceived stigma and low CD4 cell count $(<200)$ had statistically significant association with depressive symptom. Training of health workers in ART clinics and availing manuals on assessing mental health issues is useful to screen and treat depression among HIV patients.

Keywords: Depressive symptom, Perceived stigma, Social support, HIV, Ethiopia, Prevalence, Associated factors, Depression, Hawassa, South Ethiopia

\section{Background}

HIV/AIDS is one of a chronic disease which affects human immune systems and it increases vulnerability to infections and other immunological disorders [1]. Globally, different studies in 2013 revealed that an estimated 35 million people were living with HIV/AIDS, of which 24.7 million are living in Sub-Saharan Africa and 1.6 million people died related to HIV/AIDS [2]. In developing

\footnotetext{
*Correspondence: berkole.dad@gmail.com

${ }^{1}$ Faculty of Health Sciences, College of Medicine and Health Sciences,

Hawassa University, P. O. Box 1560, Hawassa, Ethiopia

Full list of author information is available at the end of the article
}

countries, 9.5 million people were receiving HIV treatment in 2012 [3].

According to the WHO 2015 report, 350 million people were affected by depression worldwide. Due to this problem, over 800,000 people die by suicide every year globally [4]. WHO estimated that the incidence of suicide related to depression will reach approximately 1.53 million people by the year 2020. Based on finding from general population study, the life-time risk of depression is one in five women and one in ten men in their lifetime [5]. 
Findings from different studies show that 121 million people living with HIV/ADIS are affected by depression globally [6]. Studies conducted in different countries on prevalence of depression among HIV patients showed $58.75 \%$ in Delhi (India) [7], 29.4\% in Brazil [8], 54.4\% in Italy [9], 37\% in United States [10], 25.4\% in South Africa $[6,11], 25.3 \%$ of women and $31.4 \%$ of men in Botswana [12], 47\% in Uganda [13], 43.9\% in Mekele, Ethiopia [14], $45.8 \%$ in Harar, Ethiopia [15] and 38.94\% in Debrebirhan, Ethiopia [16].

Depressive symptom among HIV-positive clients is associated with low income, widowed, being female, nonadherence of ART, having frequent of schedule for clinical visit in a month, low educational status, being female, age category (40-49), and having stage III and Stage IV HIV-related symptom $[16,17]$.

Being mentally impaired has been linked with an impaired adherence to ART and poor treatment outcome, decrease in CD4 count and increase in viral load. In addition, depression has been associated with highrisk behaviors like engaging in unsafe sex $[11,15,17]$.

Based on different study findings, the magnitude of depressive symptom among people living with HIV/ AIDS is high. Though it has a great impact on their treatment outcome, it was not assessed at Hawassa University Comprehensive Specialized Hospital. Therefore, this study aims to assess the prevalence and factors of depressive symptom among people living with HIV attending Hawassa University Comprehensive Specialized Hospital, ART clinic, South Ethiopia.

\section{Methods}

\section{Study setting and population}

Hospital-based cross-sectional study design was implemented from April to May 2016 at Hawassa University Comprehensive Specialized Hospital, Hawassa, Ethiopia. Among 1440 HIV patients who had regular follow-up at ART clinics, 417 study participants were recruited for the study; those unable to communicate because of their illness and those who need intensive care were excluded from the study. Study participants were included using systematic random sampling technique, $K=3$. Sixteen patients were refused to participate in the study.

\section{Data collection}

Trained and experienced nurses had collected the data using pretested interviewer administered questionnaire. The data collection tool includes socio-demographic characteristics (age, education, occupation, marital status and others). Oslo 3-item social support scale has the sum score scale ranging from 3 to 14 with three broad categories: "poor support" 3-8, "moderate support" 9-11 and "strong support" 12-14 [18]. It was reliable in our study (Cronbach's $\alpha=0.88$ ). HIV-related perceived stigma was collected by an 11-item HIV stigma scale. It consisted of four-point Likert scale (strongly disagree, disagree, agree, strongly agree) questions concerning perceived isolation, shame, guilt and disclosure of the HIV status. The item scores of the stigma questions were summed to construct a single stigma variable. Our study participants were classified as having or not having perceived stigma using the mean of the stigma variable as cutoff point $[19,20]$. The instrument was adopted and translated to Amharic language and back to English and highly reliable in the study (Cronbach's $\alpha=0.92$ ). The presence of depression was assessed by patient health questionnaires item nine (PHQ-9). It is a 9-item questionnaire, commonly used to screen for symptoms of depression in primary health care and in outpatients and validated in Ethiopia with sensitivity $=86 \%$ and specificity $=67 \%$. The scales use a cutoff score for depression of greater than or equal to 5 [21].

\section{Data processing and analyses}

SPSS version 20 was used to analyze the data. The association of each independent variable with the outcome variable was seen by bivariate analysis. In order to identify potential confounders, binary logistic regression model was used. A $p$ value of less than 0.05 was considered statistically significant and adjusted odds ratio with 95\% CI was calculated to determine association.

\section{Results}

Socio-demographic characteristics of the study participants

A total of 401 study participants were included in the study, giving a response rate of $96.2 \%$. The mean $( \pm$ SD) age of the respondents was 38 years $( \pm 10.228)$. Among the study participants, 149 (38.9\%) were in age range between 35 and 44 years, 193 (50.4\%) were orthodox religion followers, 178 (46.5\%) were married, 138 (36\%) were attended primary education, 96 (25.1\%) were house wife, and $340(88.8 \%)$ were living in urban. The median monthly income of the respondents was 875 Ethiopian birr (31.45 USD) (Table 1).

\section{Clinical and psychosocial characteristics of the study participants}

Among respondents, the maximum CD4 cell count was 1622 with a mean of $541.08 .330(86.2 \%)$ of the study participants had CD4 cell counts ranges between 200 and 1000. 357, (93.2\%) of respondents were on ART, 162 (42.3\%) were found in stage II HIV/AIDS, 259(67.6\%) had poor social support, 168 (43.9\%) had perceived stigma and $72(18.8 \%)$ were current substance (khat, alcohol, cigarette) users (Table 2). 
Table 1 Distribution of people living with HIV/AIDS at Hawassa University Comprehensive Specialized Hospital, Hawassa, Ethiopia, 2016/2017

\begin{tabular}{|c|c|c|c|}
\hline Characteristics & Category & Frequency & Percent (\%) \\
\hline \multirow[t]{2}{*}{ Sex } & Male & 129 & 29 \\
\hline & Female & 272 & 71 \\
\hline \multirow[t]{4}{*}{ Age } & $18-34$ & 141 & 36.8 \\
\hline & $35-44$ & 149 & 38.9 \\
\hline & $45-54$ & 62 & 16.2 \\
\hline & $>54$ & 31 & 8.1 \\
\hline \multirow[t]{2}{*}{ Residence } & Urban & 340 & 88.8 \\
\hline & Rural & 43 & 11.2 \\
\hline \multirow[t]{3}{*}{ Religion } & Protestant & 160 & 41.8 \\
\hline & Orthodox & 193 & 50.4 \\
\hline & Muslim & 29 & 7.6 \\
\hline \multirow[t]{4}{*}{ Educational level } & Unable to write and read & 68 & 17.8 \\
\hline & Primary education (grade 1-8) & 138 & 36 \\
\hline & Secondary education (grade 9-12) & 110 & 28.7 \\
\hline & Tertiary education (college and above) & 67 & 17.5 \\
\hline \multirow[t]{6}{*}{ Ethnicity } & Sidama & 48 & 12.5 \\
\hline & Oromo & 88 & 23.0 \\
\hline & Amhara & 93 & 24.3 \\
\hline & Wolaita & 102 & 26.6 \\
\hline & Gurage & 32 & 8.4 \\
\hline & Other & 20 & 5.2 \\
\hline \multirow[t]{5}{*}{ Marital status } & Single & 69 & 18.0 \\
\hline & Married & 178 & 46.5 \\
\hline & Separated & 19 & 5.0 \\
\hline & Divorced & 45 & 11.7 \\
\hline & Widowed/widower & 72 & 18.8 \\
\hline \multirow[t]{7}{*}{ Occupation status } & Merchant & 76 & 19.8 \\
\hline & Government employee & 65 & 17.0 \\
\hline & Privet employee & 71 & 18.5 \\
\hline & Day laborer & 33 & 8.6 \\
\hline & Student & 17 & 4.4 \\
\hline & House wife & 96 & 25.1 \\
\hline & Jobless & 25 & 6.5 \\
\hline \multirow[t]{3}{*}{ Monthly income } & $<735$ ETB per month & 199 & 52.0 \\
\hline & 735-1176ETBper month & 49 & 12.8 \\
\hline & >1176ETB per month & 135 & 35.2 \\
\hline
\end{tabular}

\section{Prevalence of depressive symptom among the study} participants

Depressive symptom was found using PHQ-9 scale. Based on the cutoff point $\geq 11,48.6 \%$ of the HIV clients had depression.

\section{Factors associated with depressive Symptoms}

Binary logistic regression analysis revealed that poor social support, CD4 count $(<200)$ and perceived HIV stigma were associated with depressive symptom (Table 3).

\section{Discussion}

Institution-based cross-sectional study was conducted to assess the prevalence and factors associated with depression among patients HIV/AIDS at Hawassa University Comprehensive specialized hospital using PHQ9. The finding of this study (48.6\%) was higher than studies in rural South Africa 42.4\% [6, 11], in Malawi 18.9\% [22], and in Ethiopia 43.9\%, 45.8\%, 38.94\% in Mekele, Harar and Debreberihan, respectively [14-16]. On the other side, the study finding was lower than studies done in Delhi (India) 58.75\% [7], North Central Nigeria 56.7\% 
Table 2 Description of clinical and psychosocial factors among people living with HIV/AIDS at Hawassa University Comprehensive Specialized Hospital, Hawassa, Ethiopia, 2016/2017

\begin{tabular}{llrc}
\hline Variables & Category & Frequency & Percent \% \\
\hline CD4 cell count & $<200$ & 33 & 8.6 \\
& $200-1000$ & 330 & 86.2 \\
& $\geq 1000$ & 20 & 5.2 \\
Started ART taking & Yes & 357 & 93.2 \\
& No & 26 & 6.8 \\
Perceived stigma & Yes & 168 & 43.9 \\
& No & 215 & 56.1 \\
Current substance & Yes & 72 & 18.8 \\
& No & 311 & 81.2 \\
HIV/AIDS stages & Stage I & 150 & 39.2 \\
& Stage II & 162 & 42.3 \\
& Stage III & 58 & 15.1 \\
& Stage IV & 13 & 3.4 \\
Social support & Poor social support & 259 & 67.6 \\
& Moderate social support & 110 & 28.7 \\
& Strong social support & 14 & 3.7 \\
\hline
\end{tabular}

[23], in Cameroon 63\% [24] and in Ethiopia [25]. The difference might be related to study design, data collection tool, sample size and study participant's variation.

HIV-related perceived stigma had significant association with depressive symptom. The finding is similar to the study done in Botswana [12], in Ethiopia [14-16, 25]. Having HIV, which is one of the chronic life-long diseases and which is prone to high levels of stigma, they may find it easier to be alone to avoid stigma or discrimination, or they may not have the energy to be socially engaged [26].

Clients who had poor social support were 2.5 times more likely to have depressive symptom when compared to clients who had strong social support $(\mathrm{AOR}=2.53$, $95 \%$ CI 1.70, 9.13). The finding was similar to the study conducted in Delhi (India) [7], in Nigeria in 2008 [27], and in North Central Nigeria in 2013 [23]. This might be due to the fact that social isolation reduces social support, which can have a negative impact on mental and physical well-being [28].

Individuals who had $<200 \mathrm{CD} 4$ cell count had significant association with depressive symptom. This was similar to the study conducted in Malawi [22], and Debrebirhan, Ethiopia [16]. This might be due to severe immune depression and HIV illness is underlining causes of depression [29].
Table 3 Factors associated with depression among people living with HIV/AIDS at Hawassa University Comprehensive Specialized Hospital, Hawassa, Ethiopia, 2016/2017

\begin{tabular}{|c|c|c|c|c|}
\hline \multirow[t]{2}{*}{ Characteristics } & \multicolumn{2}{|c|}{ Depression } & \multirow[t]{2}{*}{ COR $(95 \% \mathrm{Cl})$} & \multirow[t]{2}{*}{ AOR $(95 \% \mathrm{Cl})$} \\
\hline & Yes & No & & \\
\hline \multicolumn{5}{|l|}{ Sex } \\
\hline Female & 140 & 132 & $1.49(0.96,2.34)$ & $1.44(0.82,2.52)$ \\
\hline Male & 46 & 65 & 1 & 1 \\
\hline \multicolumn{5}{|l|}{ Age } \\
\hline $18-34$ & 74 & 67 & $1.34(0.61,2.92)$ & $1.31(0.51,3.38)$ \\
\hline $35-44$ & 62 & 87 & $0.86(0.397,1.885)$ & $0.86(0.34,2.14)$ \\
\hline $45-54$ & 36 & 26 & $1.68(0.71,4.01)$ & $1.59(0.61,4.18)$ \\
\hline$>54$ & 14 & 17 & 1 & 1 \\
\hline \multicolumn{5}{|l|}{ Educational level } \\
\hline $\begin{array}{l}\text { Unable to read and } \\
\text { write }\end{array}$ & 34 & 34 & $1.23(0.63,2.43)$ & \\
\hline Primary education & 74 & 64 & $1.43(0.79,2.26)$ & \\
\hline Secondary education & 48 & 62 & $0.96(0.52,1.76)$ & \\
\hline Tertiary education & 30 & 37 & 1 & 1 \\
\hline \multicolumn{5}{|l|}{ Marital status } \\
\hline Married & 88 & 90 & $1.52(0.86,2.67)$ & $1.76(0.89,3.46)$ \\
\hline Separated & 7 & 12 & $0.91(0.32,2.59)$ & $0.83(0.24,2.87)$ \\
\hline Divorced & 22 & 23 & $1.48(0.69,3.17)$ & $1.28(0.52,3.15)$ \\
\hline Widowed/widower & 42 & 30 & $2.17(1.11,4.27)$ & $1.78(0.72,4.38)$ \\
\hline Single & 27 & 42 & 1 & 1 \\
\hline \multicolumn{5}{|l|}{ Monthly income } \\
\hline$<735$ ETB & 105 & 94 & $1.67(1.07,2.60)$ & $1.60(0.95,2.68)$ \\
\hline $735-1176$ & 27 & 22 & $1.84(0.95,3.56)$ & $1.40(0.67,2.95)$ \\
\hline$>1176$ & 54 & 81 & 1 & 1 \\
\hline \multicolumn{5}{|l|}{ Substance use } \\
\hline Yes & 37 & 35 & $1.13(0.68,1.92)$ & \\
\hline No & 149 & 162 & 1 & 1 \\
\hline \multicolumn{5}{|l|}{ ART taking } \\
\hline Yes & 173 & 184 & $0.940(0.42,2.08)$ & \\
\hline No & 13 & 13 & 1 & 1 \\
\hline \multicolumn{5}{|l|}{ HIV/AIDS stages } \\
\hline Stage II & 74 & 88 & $0.94(0.59,1.46)$ & $0.77(0.46,1.29)$ \\
\hline Stage III & 31 & 27 & $1.27(0.69,2.35)$ & $1.02(0.49,2.10)$ \\
\hline Stage IV & 10 & 3 & $3.71(0.98,14.02)$ & $2.79(0.64,12.09)$ \\
\hline Stage I & 71 & 79 & 1 & 1 \\
\hline \multicolumn{5}{|l|}{ Perceived stigma } \\
\hline Yes & 108 & 60 & $3.16(2.08,4.82)$ & $2.83(1.78,4.48)^{* *}$ \\
\hline No & 78 & 137 & 1 & 1 \\
\hline \multicolumn{5}{|l|}{ Social support } \\
\hline Poor & 104 & 155 & $1.21(0.39,3.71)$ & $2.53(1.70,9.13)^{* *}$ \\
\hline Moderate & 77 & 33 & $4.20(1.31,13.48)$ & $7.09(1.91,26.29)^{*}$ \\
\hline Strong & 5 & 9 & 1 & 1 \\
\hline
\end{tabular}


Table 3 (continued)

\begin{tabular}{lrrll}
\hline Characteristics & \multicolumn{2}{c}{ Depression } & COR $(\mathbf{9 5} \% \mathrm{Cl})$ & AOR $(\mathbf{9 5 \%} \mathrm{Cl})$ \\
\cline { 2 - 3 } & Yes & No & & \\
\hline CD4 & 23 & 10 & $2.30(0.73,7.25)$ & $3.89(1.02,14.83)^{*}$ \\
$<200$ & 153 & 177 & $0.86(0.35,2.13)$ & $1.27(0.47,3.47)$ \\
$200-1000$ & 10 & 10 & 1 & 1 \\
$\geq 1000$ & & & &
\end{tabular}

Depression (Yes)-PHQ $\geq 11,{ }^{*}$ significant association ( $p$-value $\left.<0.05\right){ }^{* *}$ significant association ( $p$-value $<0.01$ )

Italic values represent references of the variable

Unlike other study, being female sex, being divorced and unmarried and those using substance had no statistically significant association with depression.

\section{Conclusion}

Depressive symptom was high (48.6\%) among the current study population. Perceived HIV-related stigma, poor social support and CD4 count $(<200)$ had significant association with depressive symptom. Hence, depression is highly prevalent among HIV-positive patients, still underdiagnosed and undertreated but it needs further research. Therefore, Ministry of Health should give more emphasis to those clients with depressive symptoms. Further research on risk factors of depression should be conducted to strengthen and broaden the current findings.

\section{Limitation of the study}

We did not do detailed validation study for perceived HIV-related stigma scale and Oslo 3-item social support scale.

\section{Authors' contributions}

$\mathrm{BD}$ conceived the study and was involved in the study design, reviewed the article, analysis, report writing and drafted the manuscript. EG, MZ and SM were involved in the study design and analysis. All authors read and approved the final manuscript.

\section{Author details}

${ }^{1}$ Faculty of Health Sciences, College of Medicine and Health Sciences, Hawassa University, P. O. Box 1560, Hawassa, Ethiopia. ${ }^{2}$ Hawassa University Comprehensive Specialized Hospital, Hawassa University, Hawassa, Ethiopia.

\section{Acknowledgements}

The authors appreciate the respective study institution for their help and the study participants for their cooperation in providing all necessary information.

\section{Competing interests}

The authors declare that they have no competing interests.

\section{Availability of data and materials}

All relevant data are within the paper.

\section{Consent for publication}

Not applicable.

\section{Ethical approval and consent to participate}

Ethical clearance for this study was obtained from the Research and Ethics Review Committee of College of Medicine and Health Sciences, Hawassa
University. Permission letter was obtained and submitted to Hawassa University Comprehensive Specialized Hospital. Study participants were informed about their rights to interrupt the interview at any time and written informed consent was obtained from each study participants. Confidentiality was maintained at all levels of the study. HIV-positive subjects who were found to have moderate to severe depressive symptoms had poor social support and perceived HIV-related stigma was referred to psychiatry clinics for further investigations.

\section{Funding}

No funding source.

\section{Publisher's Note}

Springer Nature remains neutral with regard to jurisdictional claims in published maps and institutional affiliations.

Received: 15 March 2018 Accepted: 21 October 2018

Published online: 30 October 2018

References

1. WHO. HIV/AIDS and mental health. Geneva: Switzerland; 2008.

2. United Nation Aquired Immunodefeciency Syndrom (UNAIDS). The global AIDS epidemic. Geneva: UNAIDS; 2013.

3. United Nation. The millennium development goals report. New York: Nations EaSAotU; 2014

4. WHO. 2012. http://www.who.int/mental_health/management/depre ssion/who_paper_depression_wfm.

5. WHO. 2012 https://www.who.int/mental_health/suicide-prevention/en/.

6. Pappin M, Edwin Wouters E, Booysen F. Anxiety and depression amongst patients enrolled in a public sector anti retroviral treatment programme in South Africa: a cross-sectional study. BMC Public Health. 2012;12:244.

7. Bhatia MS, Munjal S. Prevalence of depression in people living with HIV/ AIDS undergoing ART and factors associated with it. J Clin Diagn Res Jcdr. 2014;8:WC01.

8. Castrighini C, Gir E, Neves L, Reis R, Galva o M, Hayashido M. Depression and self-esteem of patients positive for HIV/AIDS in an inland city of Brazil. Retro Virol. 2010;7:P66.

9. Goulet JL, Molde S, Constantino SJ, Gaughan D, Selwyn PA. Psychiatric comorbidity and the long-term care of people with aids. J Urban Health. 2000;77(2):213-21.

10. Asch SM, Kilbourne AM, Gifford AL, et al. Underdiagnosis of depression in hiv: who are we missing? J Gen Intern Med. 2003;18(6):450-60.

11. Prince M, Patel V, Saxena S, Maj M, Maselko J, et al. No health without mental health. Lancet. 2007:370:859-77.

12. Gupta R, Dandu M, Packel L, Rutherford G, Leiter K, Phaladze N, et al. Depression and HIV in Botswana: a population-based study on gender-specific socio economic and behavioral correlates. PLoS ONE. 2010;5:e14252.

13. Kaharuza FM, Bunnell R, Moss S, Purcell DW, Bikaako-Kajura W, et al. Depression and CD4 cell count among persons with HIV infection in Uganda. AIDS Behav. 2006;10:105-11.

14. Berhe H, Bayray A. Prevalence of depression and associated factors among people living with HIV/AIDSI in Tigray, Ethiopia. North Ethiopia: a cross sectional hospital based study. IJPSR. 2013;4(2):765-75.

15. Mohammed M, Mengistie B, Dessie Y, Godana W. Prevalence of depression and associated factors among HIV patients seeking treatments in ART clinics at Harar Town, Eastern Ethiopia. J AIDS Clin Res. 2015;6:474.

16. Eshetu DA, Woldeyohannes SM, Alemayehu M, Techane GN, Tegegne MT, Dagne K. Prevalence of depression and associated factors among HIV/AIDS Patients attending ART Clinic at Debrebirhan referral hospital, North Showa, Amhara Region, Ethiopia. Am J Community Psychol. 2014;2(6):101-8.

17. Berg CJ, Michelson SE, Safren SA. Behavioral aspects of HIV care: adherence, depression, substance use, and HIV transmission behaviors. Infect Dis Clin North Am. 2007;21 (1):181-200.

18. Dalgard OS, Dowrick C, Lehtinen V, Vazquez-Barquero JL, Casey P, Wilkinson $\mathrm{G}$, et al. Negative life events, social support and gender difference in depression. Soc Psychiatry Psychiatr Epidemiol. 2006;41 (6):444-51. 
19. Van Rie A, Sengupta S, Pungrassami P, Balthip Q, Choonuan S, Kasetjaroen $Y$, et al. Measuring stigma associated with tuberculosis and HIV/AIDS in southern Thailand: exploratory and confirmatory factor analyses of two new scales. Trop Med Int Health. 2008;13(1):21-30.

20. Franke MF, Muñoz M, Finnegan K, Zeladita J, Sebastian JL, Bayona JN, Shin SS. Validation and abbreviation of an HIV stigma scale in an adult spanishspeaking population in urban Peru. AIDS Behav. 2010;14:189-99.

21. Gelaye B, Williams MA, Lemma S, et al. Validity of the patient health questionnaire-9 for depression screening and diagnosis in East Africa. Psychiatry Res. 2013;210(2):653-61.

22. Kim MH, Mazenga AC, Yu X, Devandra A, Nguyen C, Ahmed S, Kazembe PN, Sharp C. Factors associated with depression among adolescents living with HIV in Malawi. BMC Psychiatry. 2015;15(1):264.

23. Shittu RO, et al. Prevalence and correlates of depressive disorders among people living with HIV/AIDS, in North Central Nigeria. J AIDS Clin Res. 2013:4:251.

24. L'akoa RM, Noubiap JJ, Fang Y, Ntone FE, Kuaban C. Prevalence and correlates of depressive symptoms in HIV-positive patients: a cross-sectional study among newly diagnosed patients in Yaoundé, Cameroon. BMC psychiatry 2013;13:228
25. Endeshaw MM. Stigma: a contributing factor to depressive symptoms in people with HIV seeking Treatment at Gondar University Hospital, Master's thesis, 2012. https://digital.lib.washington.edu/researchworks/ bitstream/handle/1773/20694/Endeshaw_washington_02500_10536 .pdf?sequence $=1 \&$ isAllowed $=\mathrm{n}$

26. Wallach I, Brotman S. Ageing with HIV/AIDS: a scoping study among people aged 50 and over living in Quebec. Ageing Soc. 2013;33:1212-42.

27. Sale S, Gadanya M. Prevalence and factors associated with depression in HIV/AIDS patients aged 15-25 years at Aminu Kano Teaching Hospital, Nigeria. J Child Adolesc Ment Health. 2008;20:95-9.

28. Greysen SR, Horwitz LI, Covinsky KE, et al. Does social isolation predict hospitalization and mortality among HIVp and uninfected older veterans? J Am Geriatr Soc. 2013;61:1456-63.

29. Freeman M, Nkomo N, Kafaar Z, Kelly K. Factors associated with prevalence of mental disorder in people living with HIV/AIDS in South Africa. AIDS Care. 2007;19:1201-9.
Ready to submit your research? Choose BMC and benefit from:

- fast, convenient online submission

- thorough peer review by experienced researchers in your field

- rapid publication on acceptance

- support for research data, including large and complex data types

- gold Open Access which fosters wider collaboration and increased citations

- maximum visibility for your research: over 100M website views per year

At BMC, research is always in progress.

Learn more biomedcentral.com/submissions 